16 a 18 de outubro de 2019 - Campinas | Brasil

\title{
Desenvolvimento de Sistemas de Liberação Constituídos por Microvesículas de k-Carragena Associados ou não à Quitosana
}

\section{Laura M. Aiello*, Andréa Freitas, Gislaine R. Leonardi}

\section{Resumo}

Introdução: A encapsulação de substâncias ativas é uma tecnologia muito empregada nas indústrias cosmética e farmacêutica que compreende o empacotamento de compostos em camadas poliméricas, formando estruturas sólidas ou semi-sólidas denominadas partículas ou vesículas. O objetivo desse estudo foi desenvolver vesículas poliméricas de k-carragena revestidas ou não de quitosana e avaliar a influência do revestimento na liberação do azul de metileno. Metodologia: Para a preparação das vesículas foi utilizada a técnica de gelificação iônica a partir da extrusão de emulsões multicamadas em solução iônica de $\mathrm{KCl}$. As vesículas mais circulares e estáveis foram inseridas em veículo aquoso e fotografadas pelo microscópio Dino-Lite AM 2111 para verificação da formação do halo de liberação de azul de metileno e aferição de sua área. Resultados e Discussão: $\mathrm{O}$ uso de $\mathrm{KCl}$ mais concentrado facilitou a formação das partículas e a extrusão da emulsão multicamada com seringa com agulha permitiu a maior reprodutibilidade do processo. Não houve diferenças significativas na formação dos halos entre as formulações com ou sem revestimento de quitosana. Conclusões: As diferentes composições das vesículas de k-Carragena influenciaram no desenvolvimento das partículas, mas não houve diferenças significativas na liberação do Azul de Metileno pelas vesículas revestidas ou não de quitosana. Esse polissacarídeo não demonstrou ser ideal para revestimento de vesículas inseridas em veículo aquoso.

\section{Palavras-chave:}

Sistemas de Lberação, Vesículas Poliméricas, Biopolímeros.

\section{Introdução}

As micro ou macropartículas são sistemas de liberação que visam a proteção dos materiais encapsulados contra condições adversas do meio, o aumento de estabilidade, o direcionamento do ativo para locais específicos e sua liberação por determinado período e em velocidade controlada (HOLKEM, CODEVILLA, MENEZES, 2015). A $\kappa-$ Carragena tem sido explorada como material encapsulante devido à sua biocompatibilidade, facilidade de obtenção e participação na liberação controlada de ativos (PRAJAPATI et al., 2014). Dessa forma, esse trabalho teve como objetivo o desenvolvimento de vesículas de $\kappa$-carragena revestidas ou não de quitosana, avaliando a influência do revestimento no processo de liberação do azul de metileno em uma formulação cosmética.

\section{Resultados e Discussão}

Dentre as diversas formulações desenvolvidas, foram selecionadas aquelas que formaram partículas mais esféricas e resistentes, conforme mostrado na Tabela 1.

Tabela 1: Formulações Selecionadas

\begin{tabular}{|c|c|c|c|c|c|c|c|c|}
\hline Nome & F1 & F2 & F3 & F4 & F5 & F6 & F7 & F8 \\
\hline Água & qs & qs & qs & qs & qs & qs & qs & qS \\
\hline $\begin{array}{c}\text { Óleo de } \\
\text { Oliva }\end{array}$ & 6,67 & 6,67 & 6,67 & 13,33 & - & - & - & - \\
\hline $\begin{array}{l}\text { Óleo de } \\
\text { Girassol }\end{array}$ & - & - & - & - & 6,67 & 6,67 & 6,67 & 13,33 \\
\hline $\begin{array}{l}\text { Casei- } \\
\text { nato de } \\
\text { Sódio }\end{array}$ & 1,67 & 1,67 & 1,67 & 3,33 & 1,67 & 1,67 & 1,67 & 3,33 \\
\hline $\begin{array}{c}\text { K- } \\
\text { Carra- } \\
\text { gena }\end{array}$ & 1,33 & 2 & 2,67 & 1,33 & 1,33 & 2 & 2,67 & 1,33 \\
\hline $\begin{array}{l}\text { Azul de } \\
\text { metileno }\end{array}$ & 0,05 & 0,05 & 0,05 & 0,05 & 0,05 & 0,05 & 0,05 & 0,05 \\
\hline
\end{tabular}
$(0,6 \%)$ permitiu maior facilidade na formação das vesículas poliméricas. A adição de íons extras resulta no aumento da estrutura de hélice da k-Carragena formada no processo de gelificação e promove a agregação das hélices (BUREY, 2008). O uso de agulhas para extrusão da emulsão multicamada nessa solução salina garantiu maior reprodutibilidade do processo.

Não houve diferenças significativas nos valores das áreas dos halos de liberação entre as formulações revestidas ou não de quitosana. Esse polissacarídeo hidrofílico, ao adsorver a água do meio, leva ao intumescimento da matriz e desagregação das fibras (ASSIS; SILVA, 2003), o que, consequentemente, resulta na difusão do ativo (azul de metileno) na formulação cosmética (gel de gelana). Dessa forma, esse revestimento não se apresentou como adequado para vesículas incorporadas em veículo aquoso, facilitando a liberação do ativo.

\section{Conclusões}

Não houve alterações significativas na liberação do azul de metileno pelas partículas revestidas ou não de quitosana.

\section{Agradecimentos}

Ao Conselho Nacional de Desenvolvimento Científico e Tecnológico (CNPq) pelo apoio financeiro.

ASSIS, O., B., G.; SILVA, V., L.; Caracterização Estrutural e da Capacidade de Absorção de Água em Filmes Finos de Quitosana Processados em Diversas Concentrações. Polímeros: Ciência e Tecnologia, vol. 13, no 4, p. 223-228, 2003. BUREY, P.; BHANDARI, B., R.; HOWES, T.; GIDLEY, M., J.; Hydrocolloid Gel Particles:Formation, Characterization, and Application. Critical Reviews in Food Science and Nutrition, 48, p. 361-377, 2008

HOLKEM, A T; CODEVILLA, C; MENEZES, C R. Emulsificação gelificação iônica interna: alternativa para microencapsulação de compostos bioativos. Ciência e Natura, 27, p.116-124, 2015

PRAJAPATI, V. D. et al. Carrageenan: A Natural Seaweed Polysaccharide and Its Applications. Carbohydr. Polym. 105, p. 97-112, 2014 